\title{
PELATIHAN PEMBUATAN SABUN MINYAK JELANTAH UNTUK MENINGKATKAN KEMAMPUAN KEWIRAUSAHAAN IBU-IBU RUMAH TANGGA DI KELURAHAN PANGKALAN JATI BARU DEPOK
}

\author{
Nafiah Ariyani \\ Fakultas Ekonomi dan Bisnis, Universitas Sahid \\ Jl. Soepomo No 84, Tebet, Jakarta Selatan \\ Email Korespondensi:nafiah_ariyani@usahid.acid
}

\begin{abstract}
ABSTRAK
Pemanfaatan minyak jelantah di masyarakat yang tidak tepat sangat membahayakan lingkungan dan kesehatan manusia. Untuk itu perlu ada penyuluhan tentang cara pemanfaatan minyak jelantah secara tepat sehingga dapat menciptakan nilai ekonomi disertai dengan pemahaman kewirausahaan yang baik. Kegiatan pengabdian kepada masyarakat ini bertujuan untuk memberikan pengetahuan tentang kewirausahaan bagi ibu-ibu rumah tangga dengan memanfaatkan minyak jelantah. Materi pelatihan yang diberikan meliputi: konsep dasar kewirausahaan, unsur dan bahaya minyak jelantah, cara pembuatan sabun dari minyak jelantah dan cara pengemasannya. Metode yang digunakan dalam pelatihan adalah: ceramah, penyuluhan, tanya jawab, demonstrasi dan praktek. Selama pelatihan mitra mengikuti kegiatan pelatihan dengan baik dan bersemangat. Hasil pelatihan menunjukkan mitra memiliki pengetahuan tentang kewirausahaan dan dapat membuat sabun dari minyak jelantah serta terus mengusahakannya sebagai salah satu sumber alternatif pendapatan keluarga/kelompok.
\end{abstract}

Kata kunci: kewirausahaan, minyak jelantah, sabun

\begin{abstract}
One of the problems faced by society today is waste. The use of used cooking oil for consumption will endanger human health, whereas if it is discarded it will pollute the environment. One of the ways to overcome this problem is to reuse it in order to create economic value. This community service activity aims to provide knowledge about entrepreneurship for housewives by utilizing used cooking oil to be of economic value and to motivate housewives to become entrepreneurs. The training materials provided include: basic concepts of entrepreneurship, elements and dangers of used cooking oil, how to make soap from used cooking oil and how to pack it. The methods used in this training are: lectures, questions and answers, demonstrations, exercises / practices. In general, participants participated in the training activities well and enthusiastically. This was based on, among other things, the results of the practice they had achieved. After participating in this activity the participants can have knowledge about entrepreneurship and can make soap from used cooking oil, and cultivate it as an alternative source of family / group income.
\end{abstract}

Keywords: entrepreneurship, soap, waste cooking oil 


\section{PENDAHULUAN}

Permasalahan masyarakat memerlukan penyelesaian secara efektif yang dilakukan secara kolektif oleh berbagai elemen masyarakat. Perguruan Tinggi merupakan salah satu elemen masyarakat yang keberadaannya harus dapat membantu dalam mencari solusi atas berbagai permasalahan yang dihadapi masyarakat melalui penerapan ilmu pengetahuan dan teknologi (IPTEK). Penerapan IPTEK dapat diwujudkan melalui berbagai kegiatan yang dilaksanakan secara terencana dan sistematis. Salah satu permasalahan yang dihadapi oleh masyarakat adalah sampah. Keberadaan sampah tidak dapat dihindari. Sampah yang tidak dikelola dengan baik akan berakibat buruk bagi kesehatan lingkungan serta menimbulkan berbagai penyakit. Oleh karena itu diperlukan kerjasama berbagai pihak untuk menangani permasalahan ini.

Diantara berbagai jenis sampah, sampah rumah tangga merupakan penyumbang terbesar. Salah satu sampah rumah tangga adalah sampah minyak bekas menggoreng (atau yang biasa disebut minyak jelantah). Jumlah minyak jelantah cukup banyak, baik yang berasal dari rumah tangga maupun sisa dari olahan usaha kuliner. Minyak jelantah adalah produk yang tidak baik bagi kesehatan maupun lingkungan.

Pengetahuan masyarakat tentang bahaya penggunaan minyak jelantah maupun bahaya pembuangan sampah bagi lingkungan masih rendah. Banyak masyarakat yang membuangnya langsung ke tanah atau bahkan banyak yang mengkonsumsinya kembali. Jika dibuang ke tanah, minyak jelantah berpotensi menjadi limbah B3 (berbahaya dan beracun), berpotensi meracuni ekosistem, mengganggu keseimbangan BOD (biological oxide demand) dan COD (chemical oxide demand) pada badan-badan air yang sangat menopang kehidupan. (Erna, N., Wiwit, 2018) menyatakan dampak buruk bagi lingkungan akibat pembuangan minyak jelantah tanpa pengolahan terlebih dahulu dapat mencemari lingkungan tanah dan air

Selain cara pembuangan yang tidak tepat, masih banyak masyarakat yang memanfaatkan minyak jelantah untuk dikonsumsi. Dampak buruk bagi masyarakat yang ditimbulkan terhadap hal ini adalah menurunnya kualitas bahan pangan yang digoreng dengan minyak jelantah hingga mengakibatkan terganggunya kesehatan masyarakat. Senyawa polimer yang dihasilkan akibat pemanasan yang berulang-ulang dapat menimbulkan gejala keracunan antara lain iritasi saluran pencemaan, pembengkaan organ tubuh, diare, kanker dan depresi pertumbuhan (Tuasamu, 2018)

Untuk mengatasi hal tersebut, banyak muncul ide kreatif untuk memanfaatkan minyak jelantah agar dapat menciptakan nilai ekonomi. Beberapa produk yang dapat dihasilkan dari pengolahan minyak jelantah antara lain: biodiesel, sabun padat dan sabun cair. Khusus untuk hasil olahan yang berupa sabun dapat dimanfaatkan sebagai sabun cuci atau dapat dijadikan souvenir yang menarik untuk para tamu pada berbagai acara misalnya pernikahan dan lain lain. Pembentukan bank sampah minyak jelantah juga menjadi alternatif pengelolaan minyak jelantah yang lebih formal dan melembaga.

Untuk mendukung keberhasilan ide-ide kreatif tersebut maka perlu didukung oleh pengetahuan kewirausahaan yang baik. Pengetahuan kewirausahaan akan mendorong seseorang cermat dalam memanfaatkan potensi diri dan lingkungan. Penguasaan terhadap kewirausahaan akan memotivasi masyarakat untuk dapat mengelola minyak jelantah secara ter[at dan bernilai ekonomi. Untuk itu sangat tepat jika dilakukan pealtihan tentang kewirausahaan dalam rangka mengelola minyak jelantah.

Kegiatan pengabdian masyarakat ini merupakan salah satu kontribusi Universitas Sahid Jakarta dalam rangka memberikan pengetahuan kepada masyarakat tentang sampah 
pada umumnya dan minyak jelantah khususnya, serta pengetahuan tentang kewirausahaan untuk mendorong terciptanya ide-ide kreatif dalam memanfaatkan minyak jelantah sehingga mengurangi resiko kesehatana dan meningkatkan nilai ekonomi. Tujuan yang hendak dijangkau dari kegiatan ini adalah meningkatkan pengetahuan masyarakat tentang minyak jelantah dan pengelolaanya, sekaligus menanamkan jiwa kewirausahaan untuk mengembangkan kreatifitas dalam memanfaatkan minyak jelantah.

\section{Minyak Jelantah}

Minyak jelantah (waste cooking oil) merupakan limbah yang berasal dari penggunaan minyak goreng secara berulang. Pemakaian minyak jelantah yang berkelanjutan dapat merusak kesehatan manusia, menimbulkan penyakit kanker, dan mengakibatkan menurunnya kecerdasan generasi berikutnya. Untuk itu perlu penanganan yang tepat agar limbah minyak jelantah ini dapat bermanfaat dan tidak menimbulkan kerugian dari aspek kesehatan manusia dan lingkungan (Tamrin, 2013).

Minyak jelantah tidak baik apabila langsung dibuang ke alam. Hal ini dapat merusak ekosistem tanah dan air, karena masa jenis minyak dan air tidak sama maka akan terjadi pencemaran air yang akan menyebabkan ikan-ikan dan tumbuhan air mati. Demikian pula jika dikonsumsi, akan menimbulkan beberapa penyakit, diantaranya: infeksi bakteri, meningkatkan risiko kanker, meningkatkan risiko penyakit degeneratif, kelebihan berat badan, kolestrol tinggi, diabetes gestasional bagi wanita hamil, dan tenggorokan gatal. Oleh karena itu harus ada upaya pemanfaatan minyak jelantah dengan benar, bahkan jika memungkinkan dapat menciptakan nilai ekonomi.

Penggunaan minyak goreng yang berulang tidak hanya merusak mutu minyak goreng tersebut, tetapi juga menurunkan mutu bahan pangan yang digoreng. Hal tersebut ditunjukkan dengan meningkatnya kandungan kolesterol pada minyak goreng berulang, menurunnya nilai gizi yaitu protein dan kadar air serta meningkatnya kadar lemak sehingga jika terus terjadi dapat mengganggu kesehatan masyarakat yang mengkonsumsinya. Semakin banyak pengulangan penggorengan bilangan peroksida semakin meningkat sehingga membahayakan (Tuasamu, 2018).

Salah satu bentuk pemanfaatan minyak jelantah dari berbagai aspek adalah dengan mengubahnya melalui proses kimia menjadi biodiesel. Namun dalam hal ini tentunya membutuhkan jumlah minyak jelantah yang sangat banyak dan pengolahannya cukup rumit jika dilakukan oleh masyarakat biasa. Oleh karena itu, pemanfaatan minyak jelantah dalam skala rumah tangga yang paling tepat adalah mengolahnya sebagai sebagai bahan baku pembuatan sabun. Hal ini merupakan suatu cara pembuangan limbah minyak jelantah yang menghasilkan nilai ekonomis dan sekaligus ekologis (Sitompul, V., 2014).

\section{Kewirausahaan}

Kewirausahaan adalah kemampuan kreatif dan inovatif yang dijadikan dasar, kiat, dan sumber daya untuk mencari peluang menuju sukses (Suryana, 2011). Kewirausahaan merepresentasikan semangat, perilaku dan kemampuan untuk memberikan tanggapan yang positif trehadap peluang guna memperoleh keuntungan baik untuk diri sendiri dan atau pelayanan yang lebih baik kepada pelanggan/masyarakat. Kewirausahaan sekaligus menggambarkan cara kerja yang lebih efisien, melalui keberanian mengambil risiko, kreativitas, dan inovasi serta kemampuan manajemen (Salim Siagian, 1999).

Orang yang mampu menerapkan kewirausahaan disebut wirausaha, yaitu orangorang yang mempunyai kemampuan untuk melihat dan menilai kesempatan-kesempatan 
bisnis, mengumpulkan sumber-sumber daya yang dibutuhkan guna mengambil keuntungan daripadanya serta mengambil tindakan yang tepat, guna memastikan kesuksesan (Geoffrey G. Meredith et. Al, 1995) dalam (Suryana, 2011). Seorang yang berhasil dalam berwirausaha adalah orang yang dapat menggabungkan nilai-nilai, sifatsifat utama dan perilaku dengan bekal pengetahuan, pengalaman, sikap dan keterampilan praktis (knowledge and practice) (Suryana, 2011).

Kewirausahaan menggambarkan mengenai sifat khusus wirausaha yang meliputi kemampuan-kemampuan khusus; tindakan; dan hasil karya atau dampak tindakan yang dilakukan oleh seorang wirausaha. Kemampuan khusus adalah untuk mengerjakan sesuatu yang baru, kemampuan mencari peluang, keberanian atau kemampuan menanggung risiko dan kemampuan untuk mengembangkan ide dan sumber daya (Dewi, 2016). Sifat-sifat khusus seorang wiarausaha adalah sifat untuk bekerja keras dan berkorban, memusatkan segala daya dan berani mengambil risiko untuk mewujudkan gagasannya. Sedangkan tindakan yang menonjol dari seorang wirausaha adalah langkah nyata menggabungkan atau mengkombinasikan sumber daya, baik yang telah dimiliki maupun yang belum dimiliki untuk mewujudkan gagasannya dengan membangun suatu bisnis yang baru. Dari hasil karya seorang wiarusaha, dapat dilihat dengan munculnya perusahaan-perusahaan baru dengan produk-produk baru, teknologi baru dan lapangan kerja baru.

Menumbuhkan kewirausahaan adalah usaha untuk menumbuhkan jiwa wirausaha bagi masyarakat secara terus-menerus (Darmanto, 2016). Ada empat alasan mengapa para wirausaha (entrepreneurs) penting di dalam masyarakat, yaitu: 1. untuk mendayagunakan faktor-faktor produksi secara efektif (producing effective tasks). 2. Untuk mengidentifikasi berbagai peluang di dalam lingkungan dengan meningkatkan aktivitas yang akan memberikan manfaat kepada setiap orang (beneficial to everyone). 3. Untuk memilih pendekatan yang terbaik dalam mendayagunakan semua faktor produksi untuk meminimalkan pemborosan di dalam berbagai kegiatan kewirausahaan (minimize wastage in entrepreneurial activities). 4. Untuk kemanfaatan generasi mendatang (benefit of the future generation) (Juariyah, 2010).

\section{METODE PELAKSANAAN}

\section{Tempat Kegiatan dan Peserta}

Kegiatan pengabdian masyarakat ini dilaksanakan pada bulan Oktober-Desember 2018 di Kelurahan Pangkalan Jati Baru Kecamatan Cinere Kota Depok. Mitra kegiatan ini adalah pengurus dan anggota PKK di kelurahan tersebut yang berjumlah 20 orang. Pemilihan lokasi karena di kelurahan ini telah beroperasi bank sampah. Sehingga memperluas cakupan sampah kepada minyak jelantah relatif mudah dilakukan.

\section{Metode Pelaksanaan dan Bahan}

Kegiatan ini dilakukan berdasarkan analisis situasi dan permasalahan yang ditemukan pada mitra. Jika pengurus maupun anggota PKK mempunyai kemampuan wirausaha yang baik maka diharapkan pengelolaan sampah khususnya minyak jelantah akan semakin kreatif dan mampu meningkatkan nilai tambah secara ekonomi. Pelaksanaan kegiatan ini dilakukan dengan metode ceramah, dan praktek. Adapun mekanisme pelatihan secara keseluruhan adalah sebagai berikut (Gambar 1). 


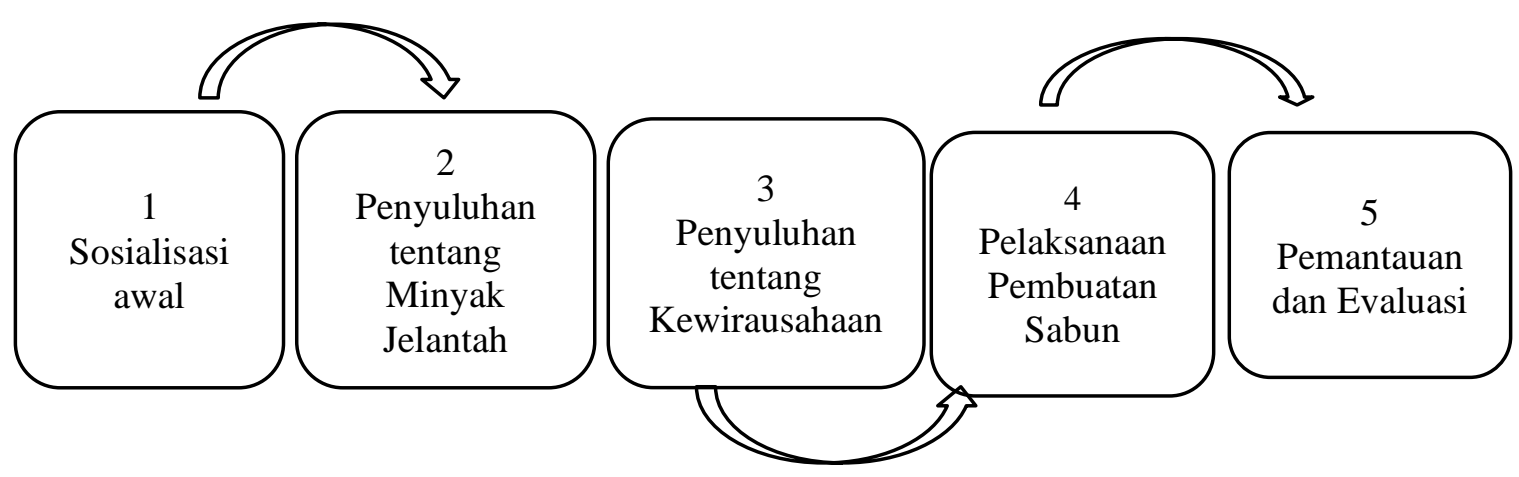

Gambar 1. Mekanisme Pelatihan Kewirausahaan dan Pembuatan Sabun Minyak Jelantah

Mekanisme kegiatan pada Gambar 1 dijelaskan sebagai berikut:

1. Sosialisasi awal

Sosialisasi awal dilakukan untuk memberikan pengenalan dan pengetahuan dasar tentang sampah dan bahaya sampah bagi masyarakat dan lingkungan. Materi pelatihan yang diberikan adalah: pengertian sampah, bahaya dan manfaat sampah, serta metode pengelolaan sampah agar memberi manfaat ekonomi.

2. Penyuluhan tentang Minyak Jelantah

Penyuluhan ini dimaksudkan untuk memberikan pemahaman kepada mitra tentang minyak jelantah, dimana mitra adalah salah satu pihak yang memproduksi dan mengkonsumsi minyak jelantah. Materi yang diberikan pada penyuluhan ini adalah: pengertian minyak jelantah, bahaya mengkonsumsi minyak jelantah, bahaya membuang sampah secara langsung ke tanah/air, alternatif-alternatif pemanfaatan minyak jelantah.

3. Penyuluhan tentang Kewirausahaan

Penyuluhan tentang kewirausahaan dimaksudkan untuk memberikan pengetahuan kepada mitra tentang konsep kewirausahaan, pentingnya mempunyai jiwa kewirausahaan dan manfaat kewirausahaan bagi ibu-ibu rumah tangga.

4. Pelatihan Pembuatan Sabun

Pelatihan pembuatan sabun dari minyak jelantah dilakukan secara demostrasi dan praktek oleh mitra. Pada praktek pembuatan sabun juga diberikan pelatihan cara membungkus sabun agar mempunyai nilai seni sehingga dapat mengoptimalkan manfaat ekonominya. Pelatihan ini dimaksudkan untuk memotivasi mitra agar mempunyai kemampuan membuat sabun dalam jumlah yang cukup dan bentuk yang indah sehingga dapat dijual atau dimanfaatkan untuk kegiatan yang berpotensi mendatangkan penghasilan bagi keluarga maupun keklompok.

Sebelum pelatihan dilaksanakan, bahan dan alat sudah terlebih dahulu disiapkan, yang meliputi sebagai berikut:

- Minyak jelantah 450 gram

- Arang secukupnya. Ditumbuk atau jadikan potongan kecil-kecil dimasukkan ke minyak sehari sebelum dipakai.

- Soda api 82,46 gram

- Pandan/sereh 7-10 lembar/kopi/aroma lain dan pewarna kue

- Air 171 gram

Adapun alat yang dibutuhkan adalah sebagai berikut:

- Pengaduk kayu 
- Spatula

- Gelas takar plastik tahan panas atau kaca

- Timbangan

- Wadah stainless steel atau wadah plastik tahan panas

- Cetakan tahan panas

- Lap dan koran bekas

- Alat pengaman: masker, kacamata pelindung, dan sarung tangan

Tahap persiapan

- Untuk mengurangi bau dan menyerap residu dari minyak jelantah, maka minyak jelantah siapkan direndam bersama arang tumbuk selama sehari sebelumnya. Lalu saring dengan kain.

Proses Pembuatan

1. Menyiapkan alat bahan dengan baik sebelum mulai.

2. Menimbang semua bahan yang diperlukan agar siap untuk dicampur atau dilarutkan.

3. Memasukkan soda api ke air pandan/air kopi ke wadah stainless. Lakukan pada ruang berventilasi bagus.

4. Menimbang minyak jelantah yang telah di saring.

5. Memasukkan minyak jelantah ke dalam larutan soda api. Aduk dengan sendok kayu sampai mencapai kekentalan yang mayones/trace, kurang lebih selama 20 menitan (tergantung jelantah apa yang dipakai, untuk minyak curah akan lebih cepat mengental). Ciri trace adalah jika pengaduk diangkat tidak meninggalkan jejak pada adonan.

6. Menuang ke dalam cetakan yang telah disiapkan dan diamkan semalam.

7. Memotong sabun menjadi ukuran yang diinginkan, lalu angin-anginkan di tempat yang berventilasi cukup.

8. Membungkus sabun dengan kain tile atau plastik dan mengemasnya dengan seni. Setelah 3-4 minggu, sabun dapat digunakan. Lebih baik lagi kalau didiamkan sampai 2-3 bulan.

\section{Pemantauan dan Evaluasi}

Untuk memantau dan meningkatkan hasil pelatihan dilakukan evaluasi dan pemantauan selama kegiatan berlangsung. Tahap pemantauan dan evaluasi dimaksudkan untuk memantau pengetahuan mitra terhadap materi yang telah diberikan. Tahap ini sekaligus dimaksudkan untuk mengatasi permasalahan yang terjadi selama kegiatan secepat mungkin. Evaluasi dilakukan dengan memberikan kuesioner kepada mitra setelah masing-masing materi diberikan.

\section{HASIL DAN PEMBAHASAN}

Kegiatan pengabdian masyarakat ini dimaksudkan untuk meningkatkan peran Universitas sahid dalam turut menyelesaikan permasalahan masyarakat. Tujuan yang hendak dijangkau adalah meningkatkan pengetahuan mitra tentang minyak jelantah dan mengelola minyak jelantah secara tepat berdasarkan prinsip wirausaha. Penyuluhan tentang kewirausahaan dan pelatihan tentang pembuatan sabun dari minyak jelantah diharapkan mampu meningkatkan pemahaman mitra tentang minyak jelantah dan cara pemanfaatannya dan tumbuhnya semangat berwirausaha dari para mitra. 
Respon dari para peserta terhadap kegiatan ini cukup antusias. Hal ini dapat dilihat dari pertanyaan dan diskusi yang dilakukan selama penyuluhan terlihat sangat bersemangat. Dengan demikian menunjukkan bahwa minat dan keinginan peserta untuk menguasai cara mengelola minyak jelantah dengan dan berwirausaha cukup besar.

Pemahaman tentang kewirausahaan mitra selama dan setelah megikuti pelatihan meningkta secara signifikan. Hal ini terlihat dari kuesioner yang dibagikan kepada peserta yang berisi pertanyaan tentang pengetahuan mereka mengenai kewirausahaan dan minat untuk berwirausaha. Hasil kuesioner menunjukkan bahwa peserta menjadi paham tentang wirausaha, memahami apa saja yang dibutuhkan untuk menjadi wirausaha dan adanya keinginan mereka untuk bisa menjadi wirausahawan.

Kendala yang dihadapi dalam kegiatan adalah jumlah minyak jelantah yang terkumpul selama pelatihan masih sedikit. Hal ini disebabkan perilaku mengonsumsi minyak jelantah oleh para mantra masih berlangsung. Alasan yang dikemukan para mitra adalah mitra merasa "sayang" membuang minyak jelantah. Kondisi ini menyebabkan jumlah sabun yang dihasilkan masih terbatas sehingga belum dapat dikomersialkan. Namun seiring dengan pemahaman yang semakin meningkat, jumlah minyak jekantah maupun sabun yang behasil dibuat berangsur meningkat pada akhir-akhir kegiatan.

Secara umum masih dihadapi sejumlah tantangan. Selain masih rendahnya kesadaran mitra untuk mengumpulkan minyak jelantah, kreativitas dalam memilih warna, cetakan, aroma dan pembungkusan juga masih rendah. Dengan pengarahan yang terus dilakukan pada minggu-minggu terkahir telah menunjukkan kecenderungan yang semakin membaik. Hal ini dapat dilihat dari volume minyak jelantah yang terkumpul semakin banyak. Demikian pula proses pembuatan sabun hasilnya semakin membaik. Demikian pula pengetahuan tentang kewirausahaan menunjukkan peningkatan.

\section{KESIMPULAN DAN SARAN}

\section{Kesimpulan}

Pelatihan kewirausahaan dan pembuatan sabun minyak jelantah di Kelurahan Pangkalan Jati Kecamatan Cinere telah berjalan dengan baik. Kesadaran mitra terhadap pengelolaan minyak jelantah telah semakin meningkat. Demikian pula terhadap pengetahuan kewirausahaan. Luaran yang dicapai dalam kegiatan pengabdian kepada masyarakat ini adalah sebagai berikut:

a. Peningkatan pemahaman mitra tentang kewirausahaan.

b. Peningkatan keinginan untuk berwirausaha.

c. Peningkatan pengetahuan tentang memanfaatkan minyak jelantah.

d. Peningkatan keterampilan membuat sabun dari minyak jelantah

\section{Saran}

Pelatihan pembuatan minyak jelantah perlu disosialisasikan kepada masyarakat secara luas. Selain membantu mengatasi permasalahan lingkungan, kegiatan ini berpotensi meningkatkan kemampuan kewirausahaan masyarakat dan memberikan nilai ekonomi dan sosial. Kegiatan ini juga menjadi media interaksi sosial yang baik bagi ibuibu. Saran yang dapat disampaikan untuk perbaikan adalah bahwa perlu dilakukan tindak lanjut terhadap kegiatan Pengabdian Kepada Masyarakat ini, dengan: 1. Melakukan pendampingan secara intensif dalam manajemen usaha. 2. Melakukan penyuluhan di bidang pemasaran, produksi, dan administrasi untuk mendukung mitra mengembangkan usaha dalam mengelola minyak jelantah. 


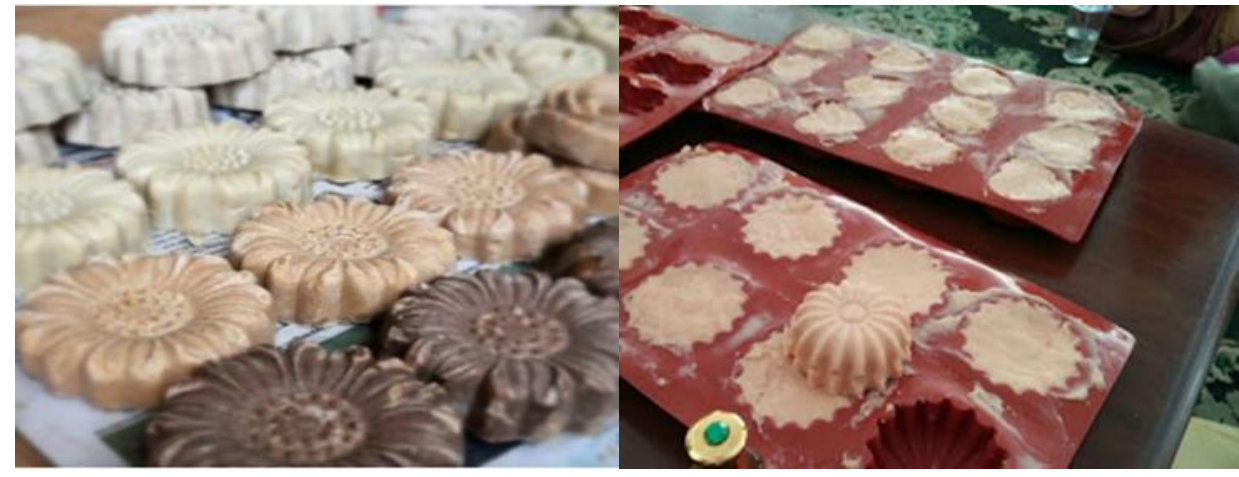

Gambar 2. Hasil Kreasi Sabun Minyak Jelantah

\section{DAFTAR PUSTAKA}

Darmanto. (2016). Kewirausahaan Untuk Mahasiswa dan UMKM. Deepublish.

Dewi, N. L. A. (2016). Pengaruh Sikap Kewirausahaan Terhadap Kemampuan Mengelola Usaha Pada Peserta Program Mahasiswa. Jurnal Program Studi Pendidikan Ekonomi (JPPE), 7(2), 1-11.

Erna, N., Wiwit, W. . (2018). Pengolahan Minyak Goreng Bekas (Jelantah) Sebagai Pengganti Bahan Bakar Minyak Tanah (Biofuel) Bagi Pedagang Gorengan Di Sekitar Fmipaunnes. Pengolahan Minyak Goreng Bekas (Jelantah) Sebagai Pengganti Bahan Bakar Minyak Tanah (Biofuel) Bagi Pedagang Gorengan Di Sekitar Fmipaunnes, 15(2), 89-95. https://doi.org/10.15294/rekayasa.v15i2.12588

Juariyah, B. dan S. (2010). Jurnal Ekonomi \& Pendidikan, Volume 7 Nomor 1, April 2010. Jurnal Ekonomi \& Pendidikan, 7(April), 58-81.

Salim Siagian. (1999). Peranan Kewirausahaan Dalam Mengembangkan Koperasi. Usahawan, 07(Juli).

Sitompul, V., A. (2014). Pemanfaatan Minyak Jelantah Untuk pembuatan Sabun. Politeknik Negeri Sriwijaya.

Suryana, Y. (2011). Kewirausahaan Pendekatan Karaktersitik Wirausahaan Sukses. Jakarta: Kencana Prenada Media Group.

Tamrin. (2013). Gasifikasi Minyak Jelantah Pada Kompor Bertekanan [ Waste Cooking Oil Gasification With Pressure Stoves ], 2(2), 115-122.

Tuasamu, R. (2018). Bahaya Penggunaan Minyak Penggorengan Berulang Dilihat Dari, (June), 1-4. 